enzyme induction in epileptic children treated with phenytoin and valproate. Neuropediatrics 1982;13: 10-13.

7 Breckenridge AM. In: Parke DVW, ed. Enzyme Induction. London: Plenum Press 1975:273.

\section{John Gilson Chair of Occupational Medicine}

Sir, Throughout his life, Dr John Gilson made outstanding contributions to research and practice in occupational medicine. During the war, his design of oxygen masks enabled RAF air crews to fly at ever higher altitudes. Subsequently, at the Medical Research Council's Pneumoconiosis Unit, which he directed from 1952 until his retirement in 1976, he developed means for producing and classifying chest radiographs and quantifying disability in coal workers' pneumoconiosis. When effective means for preventing that disease had been established, he went on to devise control measures for other pneumoconioses, notably asbestos related disease, and negotiated international agreement on their use. His success was due to combining highest academic standards with the skill of leading a multi-disciplinary team and getting employers and employees to work together. Towards the end of his life he was saddened by the decline of academic occupational medicine in the United Kingdom.

It is proposed to establish a named Chair of Occupational Medicine, as a memorial to John Gilson, at the Royal Free Hospital School of Medicine. It has the support of the President of the Royal College of Physicians of London, and its Faculty of Occupational Medicine. The Medical School's "Investment in Health" project will include this venture in its current major development in medical research and teaching of undergraduates and postgraduates.

Generous funding is needed for this memorial. Those who knew John Gilson, admired his work, and would like to contribute, are asked to send donations to The Royal Free Hospital School of Medicine, "Investment in Health" Fund, Development Office, Rowland Hill Street, London NW3 2PF.

The value of any gift can be increased by Deed of Covenant or Gift Aid, forms for which can be obtained by writing to the Development Office, or by telephoning 071-794-0500, ext 5222 , or 071-431-3887 (direct line).

CHARLES FLETCHER MARGARET GILSON RICHARD SCHILLING 11 Prior Bolton Street, London N1 2NX

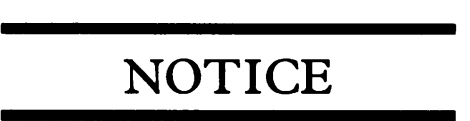

Hazard control at the workplace: research and development of new risk prevention strategies. 4th International Symposium of the ISSA Research Section, Palais des Congrès, Strasbourg, France, 2223 October 1992.

After analysing hazards at the workplace and comparing the prevention strategies that have prevailed to date (general theme), the organisers propose, in three separate workshops, each based on a particularly representative example, to debate man's role in hazard control and the implementation of new strategies. The workshops are:

Workshop 1: measuring atmospheric pollution at the workplacebiological monitoring.

Workshop 2: personal protective equipment: effectiveness and ergonomics.

Workshop 3: changing technologies and human reliability in production systems.

The findings will be aired in a round table.

This symposium should provide an opportunity for an exchange of views between the international scientific community and occupational safety and health experts; it is therefore of interest to researchers, safety engineers, occupational physicians, managers and staff, and representatives of government administrations and standardisation authorities.

Working languages: English, French, German (simultaneous interpreting).

Call for papers: To submit a paper or a poster, please send an abstract (no more than half a typed page) to the Secretariat of the Symposium by 31 October 1991. The Organising Com- mittee will make a selection and inform you of its decision by 30 January 1992.

Symposium Secretariat: INRSAtt C Skornik, 4e Colloque du Comité Recherche, 30 rue Olivier-Noyer, 75680 Paris Cedex 14, Fracne.

\section{Correction}

Computed tomography of the thorax in workers exposed to hard metals (1991;48(March):208-10).

In the third line of the final paragraph (p210) ". . . heavy metal dusts" should read ". . . hard metal dusts." 